\title{
Stormwater harvesting from landscaped areas: effect of herbicide application on water quality and usage
}

\author{
Mbanaso, FU, Nnadi, EO, Coupe, SJ \& Charlesworth, SM
}

Author post-print (accepted) deposited by Coventry University's Repository

Original citation \& hyperlink:

Mbanaso, FU, Nnadi, EO, Coupe, SJ \& Charlesworth, SM 2016, 'Stormwater harvesting from landscaped areas: effect of herbicide application on water quality and usage' Environmental Science and Pollution Research, vol 23, no. 16, pp. 15970-15982. DOI: 10.1007/s11356$\underline{016-6729-7}$

https://dx.doi.org/10.1007/s11356-016-6729-7

DOI $\quad 10.1007 / s 11356-016-6729-7$

ISSN 0944-1344

ESSN 1614-7499

Publisher: Springer Verlag (Germany)

The final publication is available at Springer via http://dx.doi.org/10.1007/s11356016-6729-7

Copyright $(C$ and Moral Rights are retained by the author(s) and/ or other copyright owners. A copy can be downloaded for personal non-commercial research or study, without prior permission or charge. This item cannot be reproduced or quoted extensively from without first obtaining permission in writing from the copyright holder(s). The content must not be changed in any way or sold commercially in any format or medium without the formal permission of the copyright holders.

This document is the author's post-print version, incorporating any revisions agreed during the peer-review process. Some differences between the published version and this version may remain and you are advised to consult the published version if you wish to cite from it. 


\section{Stormwater harvesting from landscaped areas: effect of herbicide application on water quality and usage}

F. U. Mbanaso 1,*

Phone +4402476887688

Emailmbanasof@uni.coventry.ac.uk

E. O. Nnadi

S. J. Coupe ${ }^{2}$

S. M. Charlesworth ${ }^{2}$

${ }^{1}$ Coventry University, Priory Street, Coventry CV1 5FB, United Kingdom

${ }^{2}$ Centre for Agroecology, Water and Resilience, Coventry University, Coventry, UK

4. .,

\section{Abstract}

The suitability of stormwater harvested from pervious pavement system (PPS) structures for reuse purposes was investigated in conditions where glyphosate-containing herbicides $(\mathrm{GCH})$ are applied as part of PPS maintenance procedure. The experiment was based on the four-layered design previously described as detailed in CIRIA C582. Results indicated indicate that the highest sodium absorption ratio (SAR) of 1.6 recorded in this study, 1.6, is was less than that at which loss of permeability begins to occur and as well as deterioration of matrix structure. Furthermore, the maximum electrical conductivity $(\mathrm{ECw})$ of $2990 \mu \mathrm{S} \mathrm{cm}^{-1}$, recorded for $7200 \mathrm{mg} \mathrm{L}^{-1}$ concentration was slightly below the unstable classification range at which salinity problem 
problems related to water quality eeeurs occur such that the salts accumulate in the root zone to the extent that crop yields are adversely affected. However, GCH concentration of $720 \mathrm{mg} \mathrm{L}^{-1}$ was within 'excellent' 'permissible' range while that of $72 \mathrm{mg} \mathrm{L}^{-1}$ was within 'permissible' 'excellent' range. Current study raises some environmental concerns owing to the overall impact that $\mathrm{GCH}$ at concentrations above $72 \mathrm{mg} \mathrm{L}^{-1}$ exerts on the net performance of the organic decomposers, heavy metal and hydrocarbon release from the system and thus, should be further investigated. However, effluent from all the test models including those dosed with high $\mathrm{GCH}$ concentration of $7200 \mathrm{mg} \mathrm{L}^{-1}$ do not pose any threat in terms of infiltration or deterioration associated with salinity although, there are indications that high dosage of the herbicide could lead to an elevated electrical conductivity of the recycled water.

\section{Graphical abstract}

\section{AQ1}

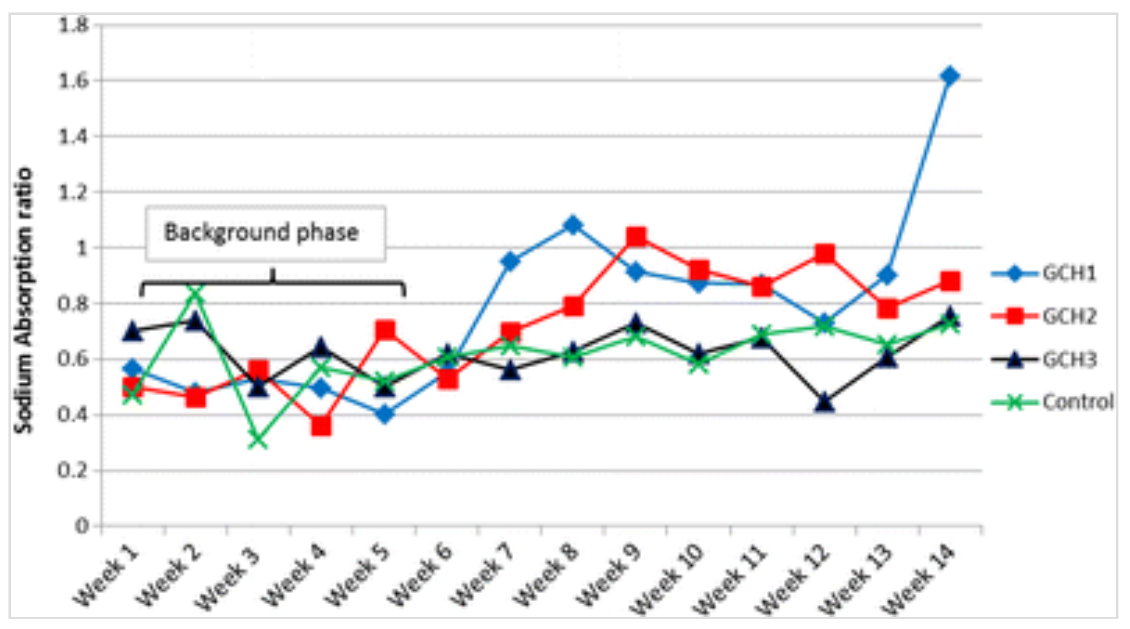

\section{Keywords}

Stormwater reuse

Glyphosate-containing herbicides

Irrigation

Water quality

Sodium absorption ratio

Sustainable drainage systems 
Responsible editor: Kenneth Mei Yee Leung

Highlights

1. PPS offers huge potential for stormwater recycling and storage.

2. Environmental concerns over impact of $\mathrm{GCH}$ at concentration above $72 \mathrm{mg} \mathrm{L}^{-1}$.

3. No infiltration, permeability or deterioration issues associated with salinity.

4. High dose of GCH may lead to elevated electrical conductivity of recycled water.

\section{Introduction}

Scarcity of water affects one in three people on every continent of the globe and this trend is projected to worsen as demand for water continues to rise as a result of increasing growth in world population, urbanisation, household and industrial usage (WHO 2014a, 2015). Currently, about 1.1 billion people in the world lack access to safe water due to impacts of climate change on water resources (WHO 2014b). Water scarcity is no longer a problem associated with poor countries alone, as the impact of climate change on water availability is being felt in both developed and developing countries. For example, in the European Union, there is a growing concern over problems of water scarcity and drought events due to long-term imbalances in water supply and availability due to climate change (Strosser et al. 2012). Also, rising water prices as a result of a 3year drought in California, USA, is driving changes in crop choices by farmers (e.g.from cotton to almonds) and in some cases, abandonment of some farmlands as well as ereated engendering increased water competition between farmers and home owners (Bjerga 2014). FAO (2013) estimates that by 2025, 1800 million people are expected to be living in countries or regions with 'absolute' water scarcity and two thirds of the world population could be under 'stress' conditions or 'water stressed'. It is therefore necessary to explore alternative water sources to augment the current shortfall in water supply in order to meet present needs and ensure sustainable development. While some alternative sources such as seawater desalination, exploitation of deeper groundwater, and 
more distant surface water reservoirs have been proposed and are being exploited in some countries, some of these sources are capital intensive and also have negative environmental impacts such as increased $\mathrm{CO}_{2}$ evolution and release of pollutants into the atmosphere (e.g. during seawater desalination process). A viable alternative is to enhance efficient utilisation of water resources, improve conservation through water saving measures and adopt water reuse procedures as a veritable substitute. While rainfall is seasonal and increasingly erratic due to climate change, rainwater is mostly wasted during the rainy seasons and consequently, water scarcity is experienced in dry seasons in the same areas annually. Hence, rater rainwater harvesting has the potential to offer solution to seasonal water scarcity in some countries particularly for lowgrade domestic uses and agricultural irrigation which accounts for $70 \%$ of world water consumption. There is a realisation that stormwater is a resource that offers huge potential to augment water demand particularly for agricultural uses (Nnadi et al. 2014). Wastewater is already being used for agricultural irrigation in many countries, particularly developing countries, but there are indications that this practice could be adopted in developed countries in drought conditions. For example, some farmers utilised recycled municipal wastewater for drip irrigation of crops as a response to the recent drought conditions in California, USA (Bjerga 2014 ). Other harvested water reuse applications include irrigation of gardens, amenity areas, golf courses, fountains, garden farms, toilet flushing, and car washing. Sustainable drainage systems (SUDS), such as pervious pavement system (PPS), offers a potential for stormwater recycling and storage for these applications (Nnadi et al. 2015). Studies have shown that the stormwater can be recycled in the PPS to almost potable water quality in terms of hydrocarbon content and presence of heavy metals (Bond 1999; Rodriguez-Hernandez et al. 2010), and has potential for application in irrigation or other uses where the use of potable quality water is unnecessary (Coupe et al. 2010). Nnadi et al. (2013) demonstrated that the PPS has the capacity to treat and store stormwater which could be used as irrigation water which that can support the growth of plants.

PPS are a commonly used component of what is known as Sustainable Drainage Systems (SUDS) in Europe and as Best Management Practices (BMPs) in the USA. Pervious pavements can be used to either infiltrate stormwater directly into the ground or to temporarily store stormwater 
before slow release to a watercourse. As well as controlling the rate and total volume of stormwater discharge from hard paved urban areas, they also provide significant improvements in the quality of water discharged or released into aquifers (Charlesworth et al. 2013). In the UK, the most common design of PPS is one which incorporates a polyolefin geotextile to separate the upper granular material (upon which concrete block paving blocks are laid) and a variety of lower, load bearing and water storage layers. This geotextile layer has been widely reported to be very important in the retention of hydrocarbons released from motor vehicles (where PPS is used as car park surface) and in encouraging the development of an oil degrading biofilm (Bond 1999; Newman et al. 2006; RodriguezHernandez et al. 2010). In order to provide water harvesting capacity, this design may incorporate an underdrain system or an underlying reservoir tank for water storage for irrigation of landscaped areas such as parks, hotel parking lots, shopping plazas, residential buildings and estates. It may also be used for creation of water features and children's parks. With increasing number of landscaped areas in the UK and other developed parts of the world, this approach offers sustainable solution to water demand, especially, during dry periods for horticultural and garden crops which are usually planted in these areas. In London, for instance, approximately two thirds of front gardens have been paved over mainly for off-road vehicular parking (London Assembly 2005). Likewise, there has been an increase in the development of impermeable surfaces on the front gardens in a sub-urban area of Leeds due to urban creep by up to $13 \%$ (Perry and Nawz 2008) Also, there is increased increasing demand for landscaped lawns and gardens in hotels in dry countries some holiday destinations by tourists who expect similar circumstances as obtainable in their home countries. This has not only increased the construction of these features, but, also put pressure on scarce water resources to maintain them especially in dry seasons. Hence, utilising the landscaped areas for water rainwater harvesting would not only provide water for irrigation of horticultural crops, lawns, and gardens as stated earlier, but would offer opportunity for low-grade applications such as toilet flushing and clothes washing. In the current study, the authors investigated the feasibility of harvesting stormwater from a surface landscaped with PPS to irrigate edible crops in gardens or green roofs and to irrigate horticultural crops in landscaped areas, e.g. hotels and public buildings, irrigation to golf courses, recreational parks, sports fields (e.g. football and rugby pitches). 
However, when these PPS are installed, they are also subject to routine maintenance protocol which includes weed control. Glyphosate-containing herbicides $(\mathrm{GCH})$ are the most widely used herbicide for weed control on hard surfaces in the world (Kempenaar 2010; Kolpin et al. 2006; Kristoffersen et al. 2008; Woodburn 2000). Herbicides have frequently been detected in excess of the EU maximum allowable concentration limit (EU MAC) of $0.1 \mu \mathrm{g} / \mathrm{L}$ for individual herbicide in the UK (Ramwell et al. 2004), Netherlands (Kempenaar et al. 2006), Belgium, Denmark, France, and Germany (European Environment Agency 2003 ). Mbanaso et al. (2012) (2013) demonstrated that the presence of GCH increases the risk of pollutants (such as heavy metals, hydrocarbons, particulates) in the effluent water and negatively affects the diversity of microorganisms required for optimal biodegradation of pollutants. While Nnadi et al. (2014) has shown that the PPS can treat stormwater to irrigation water quality and that the void spaces in the PPS structure offers huge potential for water storage, there is no study till date to indicate whether the use of herbicides such as $\mathrm{GCH}$ for weed control in PPS landscaped areas alters the irrigation water quality and renders other reuse applications ebjectionable unacceptable. Currently, there is Due to paucity of data on water quality from PPS installations which have been subjected to herbicides sprays; especially, in urban environments, as there are no previous studies to ascertain the suitability of effluent from these structures for reuse applications. The overall aim of this research is was to determine the suitability of stormwater recycled in PPS structures for irrigation in conditions whereby where herbicides such as GCH are applied as part of PPS maintenance procedure. This is particularly important as Mbanaso et al. (2013) demonstrated that the toxicity of GCH to indigenous protozoan community in the PPS at GCH weed control concentrations significantly disterted affected the ecosystem of the PPS, which is essential for pollutant pollutants removal function efficiency. Furthermore, previous studies on PPS did not consider the potential impact of application of herbicides as part of PPS maintenance strategy and hence, did not test for it.

\section{Methodology}

The test models used were the $0.0484 \mathrm{~m}^{2}$ test rigs detailed previously 
(Coupe 2004) based on the four-layered design described by Pratt (1989) as detailed in CIRIA C582 (Pratt et al. 2002). The schematic diagram of the test models are as shown in Fig. 1. The summary of the experimental set-up and analyses carried out is presented in Table 1 .

\section{Fig. 1}

Schematic of the four-layered design of the PPS

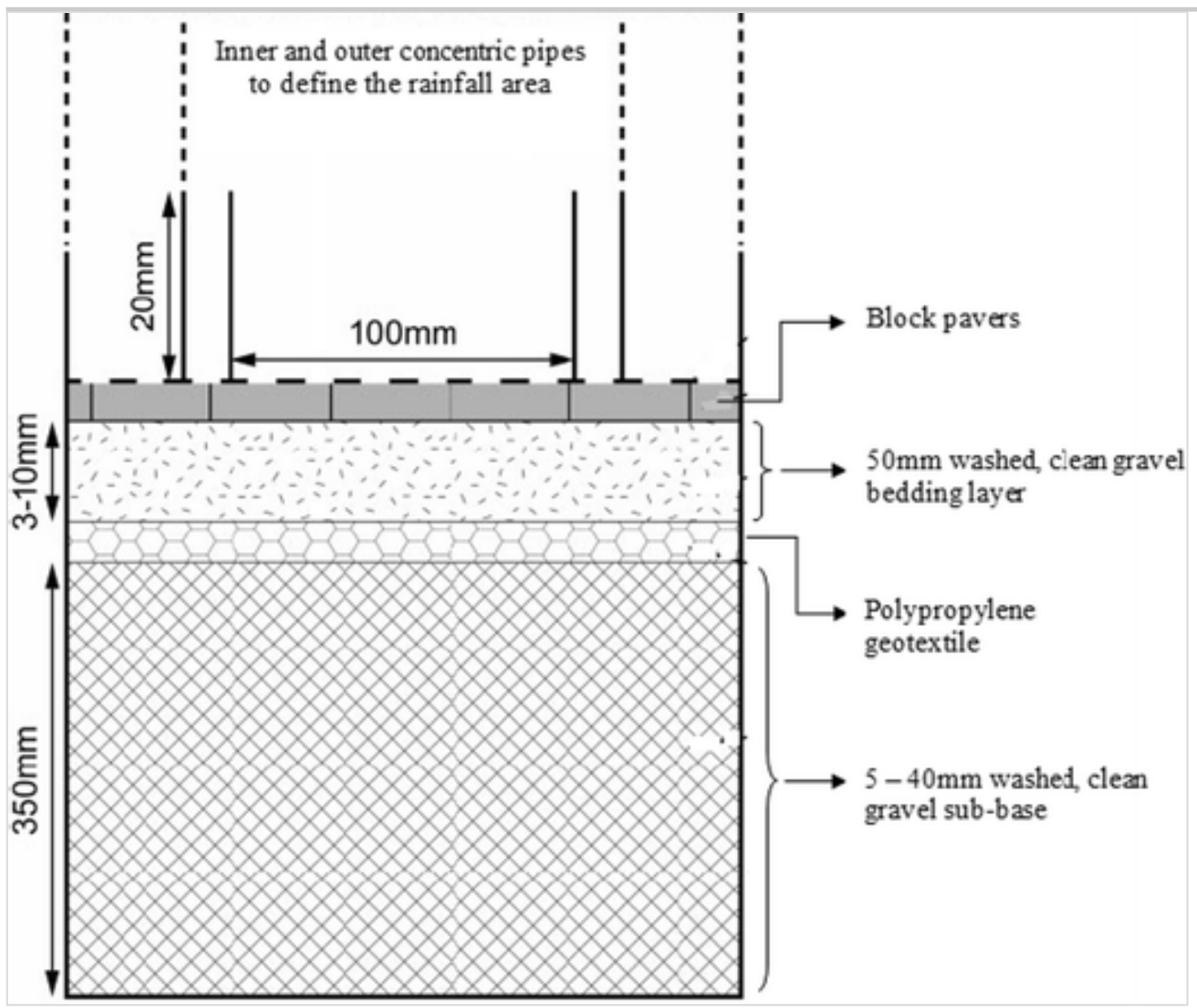

Table 1

Experimental set-up

\begin{tabular}{|c|c|c|c|}
\hline $\begin{array}{c}\text { Test } \\
\text { model }\end{array}$ & Rigs & Contaminants & Analyses \\
\hline$\frac{1}{(\mathrm{GCH} 1)}$ & $\begin{array}{l}\text { Oil }+\mathrm{GCH} \\
(7200 \mathrm{mg} / \mathrm{L})\end{array}$ & & $\begin{array}{l}\text { After physical examination of } \\
\text { effluent, it was analysed for } \\
\text { indication of microbial respiration } \\
\text { using } \mathrm{CO}_{2} \text { evolution (Pratt et al. } \\
1999 \text { ); effluent quality using } \\
\text { protists (Coupe and Smith } 2006 \text { ); }\end{array}$ \\
\hline 2 & $\begin{array}{l}\text { Oil + GCH } \\
(720 \mathrm{mg} / \mathrm{L})\end{array}$ & $\begin{array}{l}\text { Used oil and } \\
\text { GCH added on } \\
\text { weekly basis }\end{array}$ & $\begin{array}{l}\text { OES (Newman et al. 2011); } \\
\text { Hydrocarbon concentration using } \\
\text { infrared spectroscopy (Coupe } \\
2004 \text { ); hydrogen ion concentration }\end{array}$ \\
\hline
\end{tabular}




\begin{tabular}{|l|l|l|l|}
\hline $\begin{array}{l}3 \\
(\mathrm{GCH} 3)\end{array}$ & $\begin{array}{l}\text { to applicable } \\
\text { rigs followed } \\
\text { by rainfall } \\
\text { (72 } \mathrm{mg} / \mathrm{G})\end{array}$ & $\begin{array}{l}\text { using Fisherbrand Hydrus 300 pH } \\
\text { metre (Mercer and Frostick 2012); } \\
\text { effluent turbidity using an ELE } \\
\text { turbidity metre, EL430 (Pritchard } \\
\text { et al. 2009); Electrical }\end{array}$ \\
$\begin{array}{l}\text { Conductivity using Conductivity } \\
\text { metre (PTI-8 digital conductivity } \\
\text { metre) (Nnadi 2009); and } \\
\text { statistical analysis using General } \\
\text { Linear Model (univariate) on SPSS } \\
\text { and Tukey's HSD }\end{array}$ \\
\hline $\begin{array}{l}4 \\
(\text { Control) }\end{array}$ & Oil only & & \\
\hline
\end{tabular}

AQ4

\section{Addition of contaminants}

The contaminants which were considered in this study were automobileused engine oil and a proprietary $\mathrm{GCH}$. The used engine oil was added to the concentric area of the rig surfaces using a calibrated pipette as determined by a dice which was randomly thrown on the rig surfaces. The derived average oil loading based on a literature is $9.27 \mathrm{~g} \mathrm{~m}^{-2}$ year $^{-1}$, equivalent to $178 \mathrm{mg} \mathrm{m}^{-2}$ week $^{-1}$ (Bond 1999). This equates to an oil application of $1.78 \mathrm{mg} \mathrm{m}^{-2}$ week $^{-1}$ for the rig whose contaminant and rainfall application area is $0.01 \mathrm{~m}^{2}$ as shown in Fig. 1 .

There are several proprietary GCHs available at concentrations ranging from 3600 to $8400 \mathrm{mg} \mathrm{L}^{-1}$ glyphosate active ingredient. However, a glyphosate concentration of $7200 \mathrm{mg} \mathrm{L}^{-1}$ was the most common as it was the concentration most stocked by sales outlets and thus, was the concentration used. The commercial GCH formulation used was added using a trigger gun. Approximately $10 \mathrm{~mL}$ of the proprietary $\mathrm{GCH}$ was sprayed over the test area of the specified rigs on a weekly basis. After application, the rigs were then left for $1 \mathrm{~h}$ for the contaminants to infiltrate into the rigs followed by a rainfall event (Mbanaso et al. 2014).

\section{Simulation of rainfall}

Previous studies (Brownstein 1998; Bond 1999; Newman et al. 2006; Nnadi et al. 2012; Mbanaso et al. 2014) considered gentle rainfall regime of $13 \mathrm{~mm}$ to represent a typical 'rain event' and this regime was adopted for this study. Deionised water was applied to the rig surfaces by placing a plastic bowl, with 2-mm-diametre holes drilled at 5-mm spaced intervals, over the rig surface and filling with water. The reasons for the choice of 
deionised water for simulated rainwater include the following:

- Since deionised water has had mineral ions removed, the effects of contaminant application with respect to cations (e.g. sodium, calcium, iron, and copper) and anions (e.g. chloride and sulphate) are clearly discerned.

- As high-purity water, deionised water does not contain organic carbon or inorganic nutrients thereby allowing for actual evaluation of nutrient sources for microbial sustenance.

- Deionised water is readily available in the laboratory and of consistent quality.

Discharged samples from the drainage points were collected after $2 \mathrm{~h}$ to allow a representative sample to drain through. A separate sample was taken $1 \mathrm{~h}$ before the scheduled contamination and rainfall addition, to determine the extent of protist growth in the days following the previous contamination event.

\section{Analysis}

The following analyses were carried out once effluent samples were collected: physical examination of effluent, microscopic examinations for eukaryotes, metal concentration, hydrocarbon analysis, $\mathrm{pH}$ and turbidity of effluent. For statistical analysis of data, general linear model (univariate) on SPSS was used for the analysis of variance (ANOVA) while multiple comparisons of data sets were done by post hoc tests (Tukey's honestly significant difference).

\section{Physical examination}

The effluent samples were examined for colour differences, particulates, and sediments as well as other physical properties.

\section{Microscopic examination for eukaryotes}

A light microscope and Haemocytometre were used for enumeration and identification of protists (Coupe et al. 2003). Using a pipette, effluent samples were dropped onto a glass slide or counting chamber and observed at $\times 100-\times 1000$ magnification using a Leica CME microscope.

Identification was done as previously described (Lee et al. 2000; Patterson 
$1992)$.

Metal concentration in the effluent

Optical emission spectrometry was employed for the determination of the metal concentrations using an inductively coupled plasma optical emission spectrometry (ICP-OES) Optima 5300DV@ (Newman et al. 2011) supplied by PerkinElmer, USA. This equipment was calibrated using analytical grade standards supplied by Fisher Scientific, UK. From the cation data, the ratio of sodium ion to that of calcium and magnesium, i.e. sodium absorption ratio (SAR), was determined as in Suarez et al. (2006); deHayr and Gorden (2006).

\section{Total hydrocarbon content}

This was achieved by infrared spectroscopy using a Horiba OCMA 310 analyser (Nnadi 2009) which was supplied by Q Instrument Services Ltd., UK. This involves the use of trichlorotrifluoroethylene solvent (S-316) to extract the oil components from samples which are then measured using infrared spectroscopy. Equipment detection limit is in the range 0 $200 \mathrm{mg} \mathrm{L}^{-1}$. Equipment calibration was achieved by combining the standard and S-316 solvent in a 2:1 ratio.

\section{Potential of hydrogen $(\mathrm{pH})$}

Fisherbrand Hydrus 300 pH metre manufactured by Orion Research Inc., USA, was used for $\mathrm{pH}$ measurement (Mercer and Frostick 2012).

Equipment calibration was carried out using pH 4.00 and $\mathrm{pH} 7.00$ buffers.

\section{Effluent turbidity}

The turbidity of the effluent samples were measured using an ELE turbidity metre, EL430 (Pritchard et al. 2009), manufactured by ELE International Limited, UK. Equipment calibration was achieved using 4000 TU standards.

\section{Electrical conductivity}

The changes to electrical conductivity of water $(\mathrm{ECw})$ were determined by the use of calibrated PTI- 8 digital conductivity metre supplied by Scientific Industries International Inc., UK, as previously described (Jambrak et al. 2008). 
Further water quality assessments were carried out by determining the sodium absorption ratio (SAR) and Electrical conductivity of the effluent $\left(\mathrm{EC}_{\mathrm{w}}\right)$. The $\mathrm{SAR}$ and $\mathrm{EC}_{\mathrm{w}}$ are water quality parameters which are of paramount significance when considering recycling for irrigation purposes (Nnadi et al. 2013). Although there are other parameters such as soluble sodium percentage (SSP), exchangeable sodium percentage (ESP), magnesium hazards $(\mathrm{MH})$, the characteristics of water which are of vital importance in determining its suitability for irrigation purposes include the following:

- The SAR which is the relative proportion of sodium to calcium and magnesium ion concentrations (Ashraf and Harris 2004; Al-Shammiri et al. 2005; Nnadi et al. 2008),

- An assessment of impact of irrigation water on soil structure based on electrical conductivity $\left(\mathrm{EC}_{\mathrm{w}}\right)$ and SAR (deHayr and Gorden 2006),

- The aggregate of the concentration of soluble salts (Nnadi et al. 2013 ),

The SAR, calculated in milliequivalent per liter (meq/L) was computed from the following equation:

$$
\mathrm{SAR}=\frac{\left[\mathrm{Na}^{+}\right]}{\sqrt{\frac{1}{2}\left(\left[\mathrm{Ca}^{2+}\right]+\left[\mathrm{Mg}^{2+}\right]\right)}}
$$

deHayr and Gorden (2006)

AQ6

The ECw, often referred to as a specific conductance or salinity of irrigation water is an indirect measure of ions or charged particles present in the water using an electrode (Bauder et al. 2008). The classification of irrigation water based on ECw is presented in Table 2 .

\section{Table 2}

Classification of irrigation water based on ECw (Bauder et al. 2008)

\begin{tabular}{|c|c|c|}
\hline $\begin{array}{c}\text { Classes of irrigation } \\
\text { water }\end{array}$ & $\begin{array}{c}\mathrm{EC}_{\mathrm{w}} \\
(\mu \mathrm{S} / \mathrm{cm})\end{array}$ & $\begin{array}{c}\text { Maximum concentration from test } \\
\text { models }\end{array}$
\end{tabular}




\begin{tabular}{|l|l|l|}
\hline Excellent & $\leq 250$ & GCH3 and Control models \\
\hline Good & $250-750$ & - \\
\hline Permissible & $760-2000$ & GCH2 model \\
\hline Doubtful & $2010-3000$ & GCH1 model \\
\hline Unstable & $\geq 3000$ & - \\
\hline
\end{tabular}

\section{Results and discussion}

\section{Physical examination}

Effluent samples from rigs to which $\mathrm{GCH}$ was applied had varying degrees of cloudiness depending on the concentration of applied GCH while samples from the control rigs were clear and devoid of sediments. Accordingly, the order scale of cloudiness was in the following order: $\mathrm{GCH} 1>\mathrm{GCH} 2>\mathrm{GCH} 3$. Similar trend of intensity was also observed in terms of observable oil sheen as well as foam formation when agitated. The presence of cloudiness, oil sheen and foaming foam especially in samples with high concentration of $\mathrm{GCH}$ indicate potential for leaching down to aquifers and surface waters after its application on the PPS. Although GCH is claimed to adsorb strongly onto soil particles (Borggaard 2011; Mamy et al. 2008; Andrea et al. 2003 ) thereby preventing leaching potential, the loosely packed PPS aggregates (with voids) may have facilitated the infiltration of $\mathrm{GCH}$ and hydrocarbons through the rig structure with potential risk to ground and surface water systems.

\section{Microscopic examination of protists}

The effect of different concentrations of $\mathrm{GCH}$ on the protist community varied with concentration of the formulation as shown in Fig. 2. Enumeration commenced in week 6 which was the first day of contaminants addition when presence of organisms was observed.

\section{Fig. 2}

Mean number of protists in effluent from test rigs. Peak heights indicate protists growth level prior to contaminants addition. The standard deviation of the triplicate measurements was low in many cases, hence, error bars are not visible 


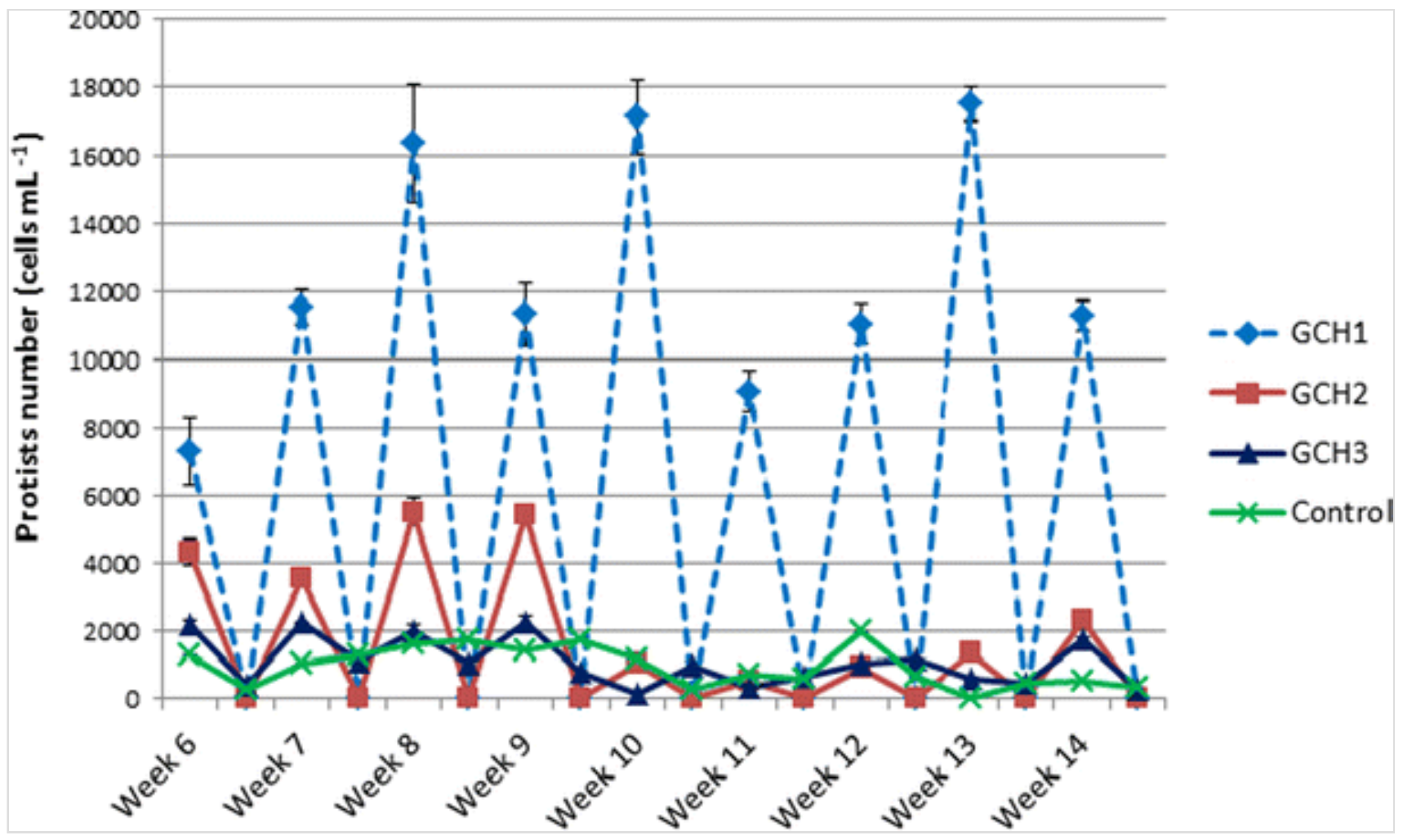

GCH1 had the most adverse effect on the microorganisms as their population was instantly wiped out as there were virtually no observable living organisms which could be sighted using the microscope. However, the protist community recovered after 7 days with growth levels averaging more than double of those of GCH 2 models and five times more than those of GCH 3.

Furthermore, protists in GCH 2 models experienced similar catastrophic impact as those of GCH 1 models but their population after the 7 days recovery period was far less than those of GCH1. A significant difference exists between $\mathrm{GCH} 2$ and $\mathrm{GCH} 3$ models in terms of post-contamination population of protists $(p<0.05)$. But the growth levels in $\mathrm{GCH} 3$ and control models were relatively identical and were characterised by less fluctuation in development trend when compared with those of GCH1 and $\mathrm{GCH} 2$. The major protists found in the models after the addition of contaminants were the ciliates and the flagellates as they were present in relatively high numbers especially in $\mathrm{GCH} 3$ models which happened to have accommodated the highest number of protist taxa.

The presence of protists in wastewater treatment systems is important as they promote ecosystem balance. Biotic components in wastewater treatment processes are represented by decomposers (bacteria, fungi) and consumers (protists and small metazoans) (Papadimitriou et al. 2004). 
These components are used in treatment systems such as activated sludges where sewage and industrial wastewaters are treated using air and a biological floc composed of bacteria and protists. Protists play a key role in the sedimentation process by removal of the dispersed bacteria through grazing, which otherwise may cause high effluent turbidity associated with water-borne diseases (Nicolau et al. 2001). Their relative presence can be used as an indicator of effluent quality (Salvado et al. 1995; Curds 1982). Effluent (water) discharged from a PPS or stored in the system for reuse has also been identified as a potential source of water for irrigation and other uses, where highly treated potable water may not be required (Nnadi et al. 2009). However, in the present study where GCH was added, concentrations of 7200 and $720 \mathrm{mg} \mathrm{L}^{-1}$ were toxic to the protist community due to catastrophic impacts while concentration of $72 \mathrm{mg} \mathrm{L}^{-1}$ showed minimal impacts as some of the morphological groups were accommodated. Obviously, this raises some environmental concerns owing to the overall impact this will exert on the net performance of the decomposers as, according to Beck et al. (1989), decomposition of pollutants may be delayed by at least $39 \%$ (18 months).

\section{Metal concentration in the effluent}

Heavy metal analyses of the effluent samples from the test rigs indicate that they did not exceed the regulatory limits (i.e. FAO, US EPA limits etc.) except for those of $\mathrm{Mg}$ (Table 3 ).

\section{Table 3}

Elemental analysis of rig effluent (maximum concentrations obtained) in comparis different international standards (where ngv represents no guideline value)

\begin{tabular}{|l|c|c|c|c|c|c|c|c|c|}
\hline \multirow{3}{*}{ Rigs } & \multicolumn{9}{c|}{ Maximum concentration $\left(\mathbf{m g ~ L}^{-\mathbf{1}}\right)$} \\
\cline { 2 - 11 } & $\mathbf{A l}$ & $\mathbf{C a}$ & $\mathbf{C d}$ & $\mathbf{K}$ & $\mathbf{M g}$ & $\mathbf{N a}$ & $\mathbf{Z n}$ & $\mathbf{F e}$ & $\mathbf{C u}$ \\
\hline GCH1 & 0.050 & 98.1 & 0.003 & 566.8 & 11.7 & 36.11 & 2.077 & 0.348 & 0.145 \\
\hline GCH2 & 0.013 & 108.9 & 0.001 & 174.9 & 10.1 & 32.97 & 1.093 & 0.178 & 0.090 \\
\hline GCH3 & 0.008 & 37.9 & 0.001 & 14.0 & 3.4 & 14.90 & 0.143 & 0.037 & 0.024 \\
\hline Control & 0.010 & 33.7 & 0.001 & 14.6 & 3.8 & 14.27 & 0.101 & 0.031 & 0.021 \\
\hline $\begin{array}{l}\text { FAO } \\
\text { limits }\end{array}$ & 5.0 & ngv & 0.01 & ngv & 0.2 & ngv & 2.0 & ngv & 0.2 \\
\hline US EPA & & & & & & & & & \\
\hline
\end{tabular}




\begin{tabular}{l|l|l|l|l|l|l|l|l|l|} 
limits $^{\mathrm{b}}$ & 5.0 & $\mathrm{ngv}$ & 0.01 & $\mathrm{ngv}$ & 0.2 & $\mathrm{ngv}$ & 2.0 & 5.0 & 0.2 \\
$\begin{array}{l}\text { Standard } \\
\text { limits }^{\mathrm{c}}\end{array}$ & 5.0 & $\mathrm{ngv}$ & 0.01 & $\mathrm{ngv}$ & $\mathrm{ngv}$ & $\mathrm{ngv}$ & $<0.05$ & 5.0 & 0.2
\end{tabular}

${ }^{1} \mathrm{FAO}(2008)$

${ }^{2}$ US EPA (2012)

${ }^{3}$ Al-Shammiri et al. (2005)

Some authors (e.g. Landschoot 2014; Duncan et al. 2000) recommend recommended that magnesium concentration in irrigation water between 10 and $25 \mathrm{mg} \mathrm{L}^{-1}$ is normal for irrigation purposes and will not have any negative effect on plant growth and soil structure. While Spectrum (2008) considers magnesium concentration between 9 and $16 \mathrm{mg} \mathrm{L}^{-1}$ to be low for irrigation purposes, Bailey et al. (1999) recommended that a concentration range between 0 and $24 \mathrm{mg} \mathrm{L}^{-1}$ is a normal range for irrigation water quality. Thus, the maximum concentration of $11.7 \mathrm{mg} \mathrm{L}^{-1}$ found in $\mathrm{GCH} 1$ models in this study is within the recommended range and therefore suitable for use in irrigation applications.

The SAR of effluent samples from the test rigs throughout the duration of the experiment is presented in Fig. $z 3$ while the $\mathrm{ECW}$ is presented in Fig. 34 . When SAR of water is $>9$, it is an indication of permeability problems (Harivandi 1982) and may limit infiltration of water (Warrence et al. 2003 ). The highest SAR recorded in this experiment was 1.6 by GCH1 while GCH2 and GCH3 were 1.0 and 0.8 , respectively. Control model recorded a maximum value of 0.7 in the 14 th week. Relatively high SAR values can cause infiltration problems as the infiltration rate of water may be reduced (Horneck et al. 2007), deterioration of matrix structure and reduction of permeability (Oster and Shainberg 2001). High salinity in the root zone can make it difficult for roots to extract water thus, causing reduction in crop yield. Osmotic potential may also be increased thereby triggering water movement from areas of low salt concentration (e.g. plant tissue) to areas of high salt concentration (e.g. soil, PPS) which may cause plants to wilt or die (Halliwell et al. 2001). While studying the effects of treating domestic wastewater, Patterson (1994) observed loss of permeability at SAR value of 3 although, the universally accepted level 
above which permeability and structural stability may occur is at SAR value of 6 (Suarez et al. 2006; Oster et al. 1992) while, Anzeec (2000) suggests SAR value of 8 as the higher limit for irrigation of non-tolerant plants. In the present study, effluent SAR from all the test rigs during the 14-week duration of the experiment did not exceed 72 . This is less than the value at which loss of permeability begins to occur (Patterson 1994) as well as the universally accepted SAR value of 6 . This demonstrates that the effluent from all the test models including those dosed with high $\mathrm{GCH}$ concentration of $7.2 \mathrm{~g} \mathrm{~L}^{-1}$ do not pose any threat in terms of infiltration, permeability or deterioration associated with salinity. Therefore, PPS exposed to $\mathrm{GCH}$ during weed control has the capacity to treat and recycle stormwater for reuse in agricultural irrigation.

\section{Fig. 3}

Effluent SAR of the different concentrations of GCH. GCH1 $=7200 \mathrm{mg} \mathrm{L}^{-1}$, $\mathrm{GCH} 2=720 \mathrm{mg} \mathrm{L}^{-1}$ and $\mathrm{GCH} 3=72 \mathrm{mg} \mathrm{L}^{-1}$

\section{$\mathrm{AQ7}$}

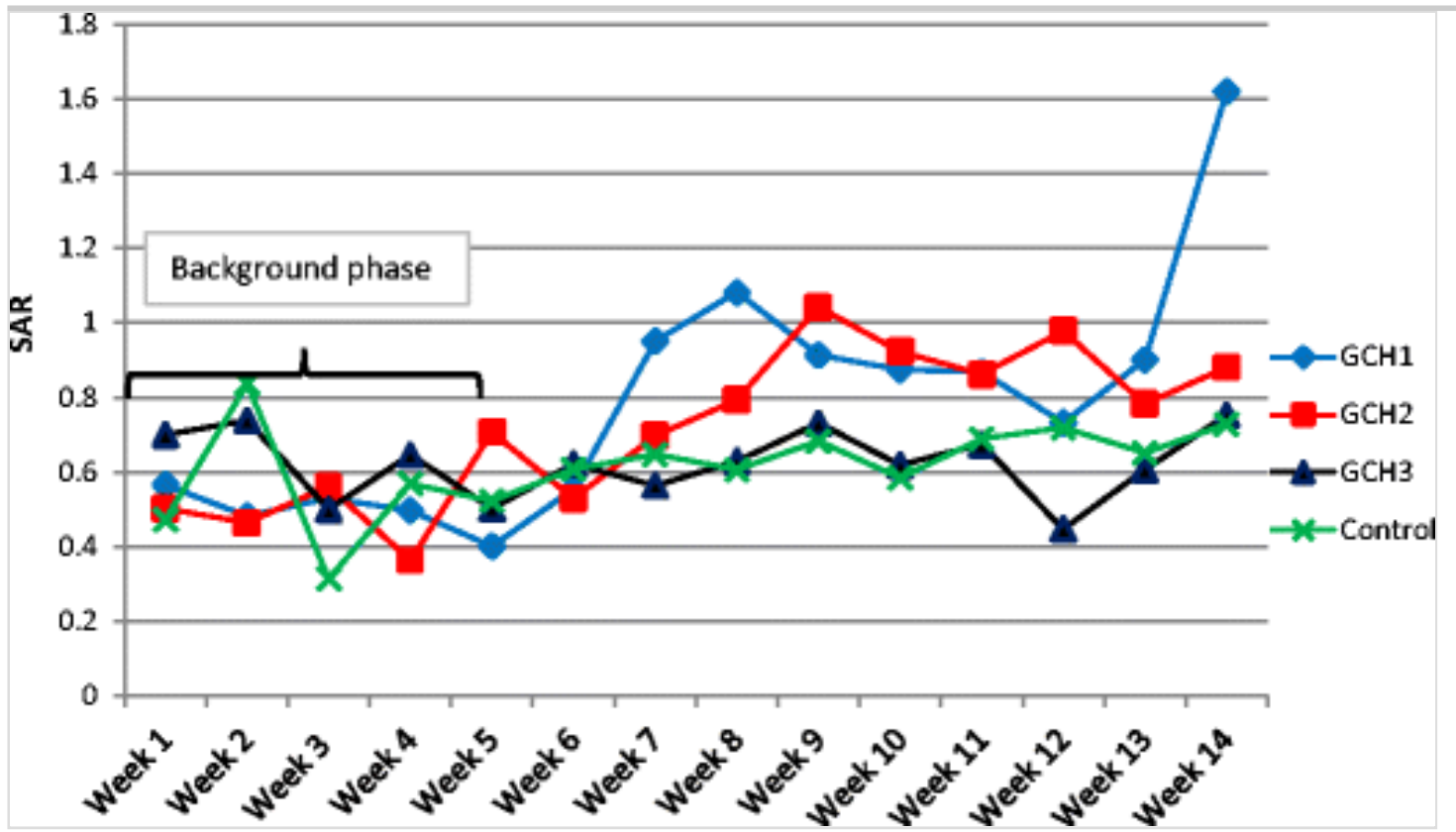

The maximum ECw values recorded during post-contamination phase of the study for $\mathrm{GCH} 1$ and $\mathrm{GCH} 2$ were 2990 and $1152 \mu \mathrm{S} \mathrm{cm}^{-1}$, respectively, while $187 \mu \mathrm{S} \mathrm{cm}^{-1}$ was recorded for GCH3 model (Fig. 4). ECw measures the ability of the effluent solution to conduct electricity and as a measure of dissolved salts in effluent. Since pure water is a poor conductor of electricity, increases in soluble salts result in proportional increases in the solution EC (Sonan et al. 2012). Different crops have different degrees of tolerance to salinity — while some are adversely affected at low ECw (i.e. 
low salt concentrations), others experience no impacts even at higher $\mathrm{ECW}$ (high salt concentrations). For instance, at EC of $8000 \mu \mathrm{S} \mathrm{cm}^{-1}$, there is no adverse impact on barley yield whereas, at EC of $1800 \mu \mathrm{S} \mathrm{cm}^{-1}$, yield of strawberries is expected to may be reduced by $25 \%$ (Horneck et al. 2007). In the current study, the maximum ECw value of $2990 \mu \mathrm{S} \mathrm{cm}^{-1}$, recorded for GCH1, was slightly below the unstable classification range (Table 2). While GCH3 was within 'excellent' range $\left(187 \mu \mathrm{S} \mathrm{cm}^{-1}\right)$, GCH2 was within 'permissible' range $\left(1152 \mu \mathrm{S} \mathrm{cm}{ }^{-1}\right)$. However, GCH1 was within range of environmental concern due to proximity to unstable region and, should therefore be closely monitored. This has become necessary especially, in temperate countries where use of salts for de-icing activities during winter is likely to increase the concentration of salts on PPS structures. This also applies to coastal environments where 'salty rain' is prevalent.

\section{Fig. 4}

Mean electrical conductivity of effluent. Error bars represent the mean \pm S.E. of three replicates. $\mathrm{GCH} 1=7200 \mathrm{mg} \mathrm{L}^{-1}, \mathrm{GCH} 2=720 \mathrm{mg} \mathrm{L}^{-1}$ and $\mathrm{GCH} 3=72 \mathrm{mg} \mathrm{L}^{-1}$

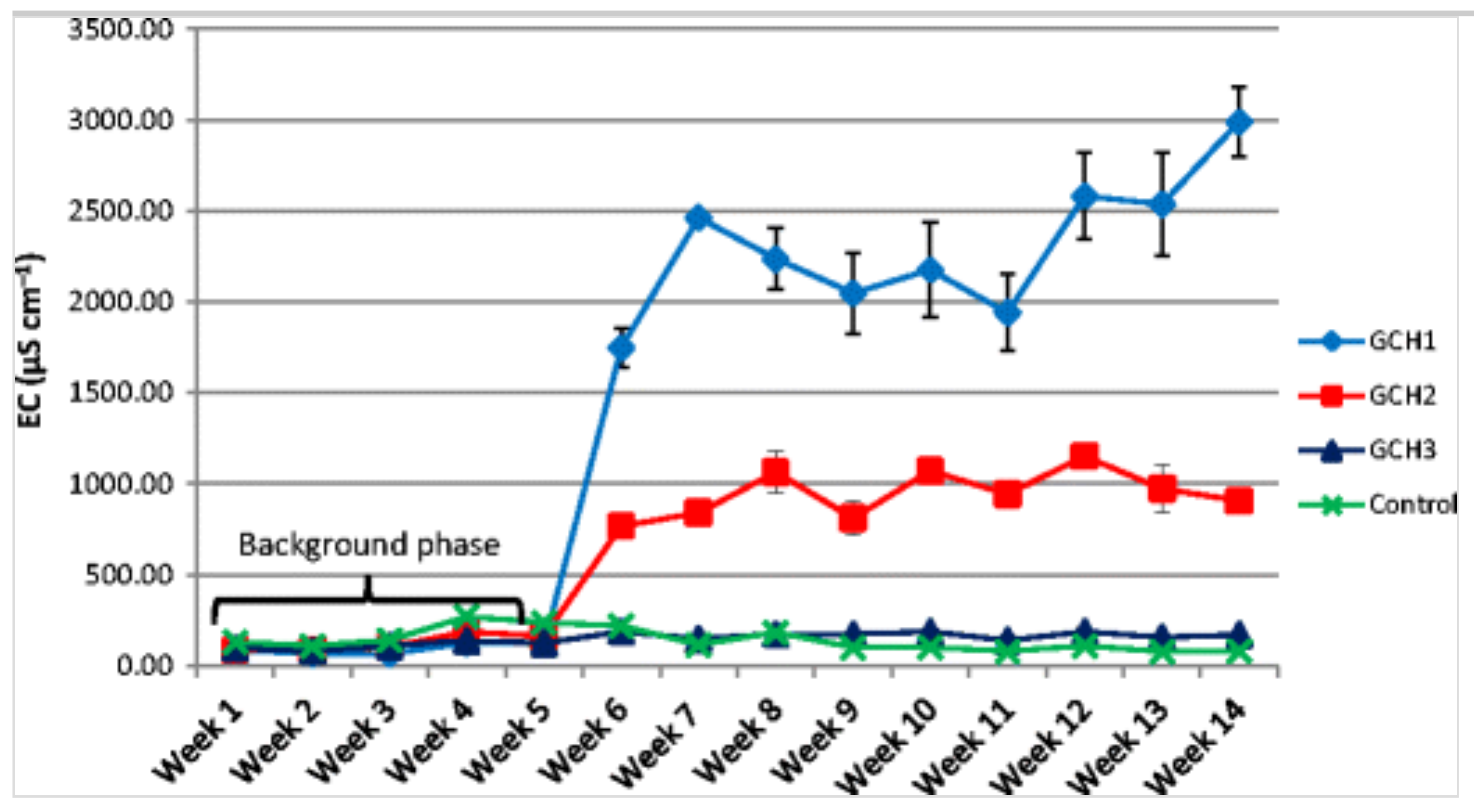

However, Bauder et al. (2011) observed that the potential soil infiltration and permeability problems arising from the use of irrigation water with high SAR cannot be sufficiently evaluated on the basis of the SAR alone. This is due to the fact that the swelling potential found in water with low $\mathrm{ECW}$ is greater than that found in water with high $\mathrm{ECW}$ at the same sodium content. Thus, they recommended that a more accurate evaluation of the 
infiltration/ permeability hazard requires the use of ECw together with the SAR.

Based on studies carried out with soils in India, Gupta (1994) classified all waters with $\mathrm{ECw}<2000 \mu \mathrm{S} \mathrm{cm}^{-1}$ and $\mathrm{SAR}<10$ as good for irrigation. Ayers and Westcot (1985) noted that at $\mathrm{ECw}=1000 \mu \mathrm{S} \mathrm{cm}^{-1}$, there is no impact on infiltration when $\mathrm{SAR}<3$ but, a severe reduction occur when $\mathrm{SAR}>13$ while, at $\mathrm{ECW}=2000 \mu \mathrm{S} \mathrm{cm}^{-1}$, no impacts when $\mathrm{SAR}<3$ but, a severe reduction when $\mathrm{SAR}>21$. According to Oster et al. (1992), infiltration problems are unlikely to occur at SAR between 3 and 6 when $\mathrm{ECw}>1000 \mu \mathrm{S} \mathrm{cm}^{-1}$ but, likely when $\mathrm{ECw}<400 \mu \mathrm{S} \mathrm{cm}^{-1}$. From the forgoing, it is eonfirmatory evident that the effluent from all the models are suitable for irrigation purposes although those of GCH1 rigs should be closely monitored due to high $\mathrm{ECW}$ values recorded.

\section{Total hydrocarbon content}

The result of the hydrocarbon analysis (Fig. 5 ) indicated that $\mathrm{GCH}$ had the capacity to wash out hydrocarbons from the rig system as different concentrations of $\mathrm{GCH}$ distorted the usual trapping of hydrocarbons (up to $98.7 \%$ ) by the geotextile (Bond 1999; Coupe 2004; Newman et al. 2001 ) by releasing oil through the rigs. This changed the operation of the PPS system although the impact was minimal in the lower concentration models.

\section{Fig. 5}

Total hydrocarbon content: Weeks 1 to 5 were to establish background. Contaminants were added in Week 6 followed by weekly additions. Error bars represent the mean \pm S.E. of three replicates. Hydrocarbon was below detection limits from weeks 1 to 5 in all treatments except in control rigs where it was below detection limits throughout. $\mathrm{GCH} 1=7200 \mathrm{mg} \mathrm{L}^{-1}$, $\mathrm{GCH} 2=720 \mathrm{mg} \mathrm{L}^{-1}$ and $\mathrm{GCH} 3=72 \mathrm{mg} \mathrm{L}^{-1}$ 


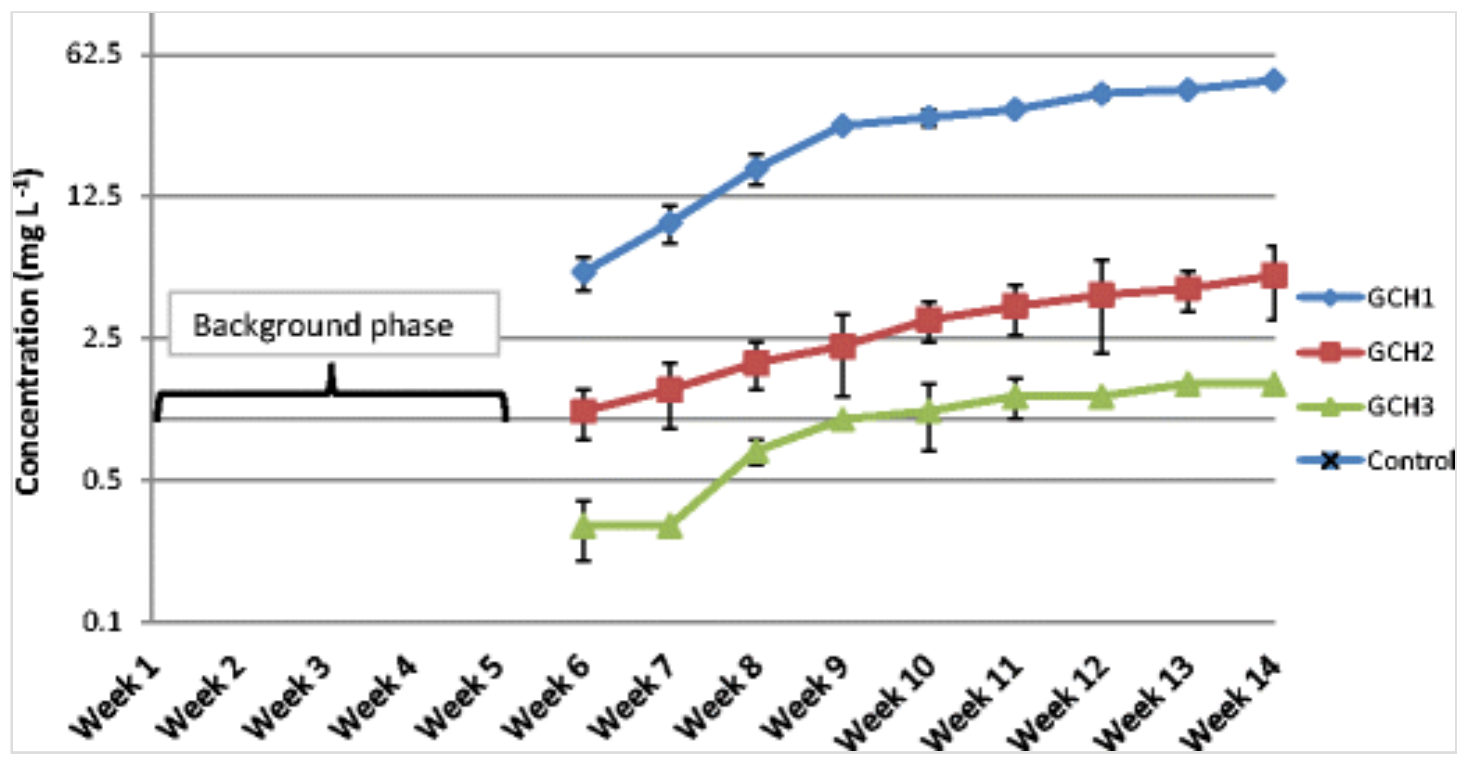

The three concentrations of GCH negatively impacted hydrocarbon retention as oil and the implication of this is that there is a potential for contamination of water systems once they are released. The design of the PPS with incorporated geotextile fibre is to ensure that contaminants such as hydrocarbons are trapped on its surface and preyed upon by microbes able to utilise it as nutrient source for growth and metabolism. However, the present study indicates that the surfactants incorporated in $\mathrm{GCH}$ distorted this function although hydrocarbon release was minimal at lower concentrations of GCH. This suggests that there might be need to reappraise the concentration of GCH readily available GCH and reconsider the current trend where arbitrary concentrations of $\mathrm{GCH}$ are made available commercially available.

\section{Potential of hydrogen $(\mathrm{pH})$}

The $\mathrm{pH}$ of the treatments showed a general reduction in initial alkalinity (Fig. 6). The potency of hydrogen (pH) in an environment is a very important parameter as its concentration can influence or alter the reaction or equilibrium mechanism. The $\mathrm{pH}$ has been identified as an environmental factor which can modify the toxicity of pesticides (Fisher 1990; Howe et al. 1994). The $\mathrm{pH}$ of soils determines the ionisation of glyphosate (Mamy and Barriuso 2005) and it is also a key variable in the determination of glyphosate adsorption (Morillo et al. 2000). In adsorption studies, $\mathrm{pH}$ has been found to be a vital parameter in the determination of adsorption capacity and trend of solutes and solutions. In the case of $\mathrm{GCH}$, it has generally been found that glyphosate adsorption varies inversely with the $\mathrm{pH}$ of the system or environment (McConnell and Hossner 1985; Morillo 
et al. 1997; Day et al. 1997) as GCH has a pH of 4.6 (Amorós et al. 2007).

\section{Fig. 6}

The $\mathrm{pH}$ of effluent from test models. Error bars represent the mean \pm S.E. of three replicates. $\mathrm{GCH} 1=7200 \mathrm{mg} \mathrm{L}-1, \mathrm{GCH} 2=720 \mathrm{mg} \mathrm{L}-1$ and $\mathrm{GCH} 3=$ $72 \mathrm{mg} \mathrm{L}-1$.

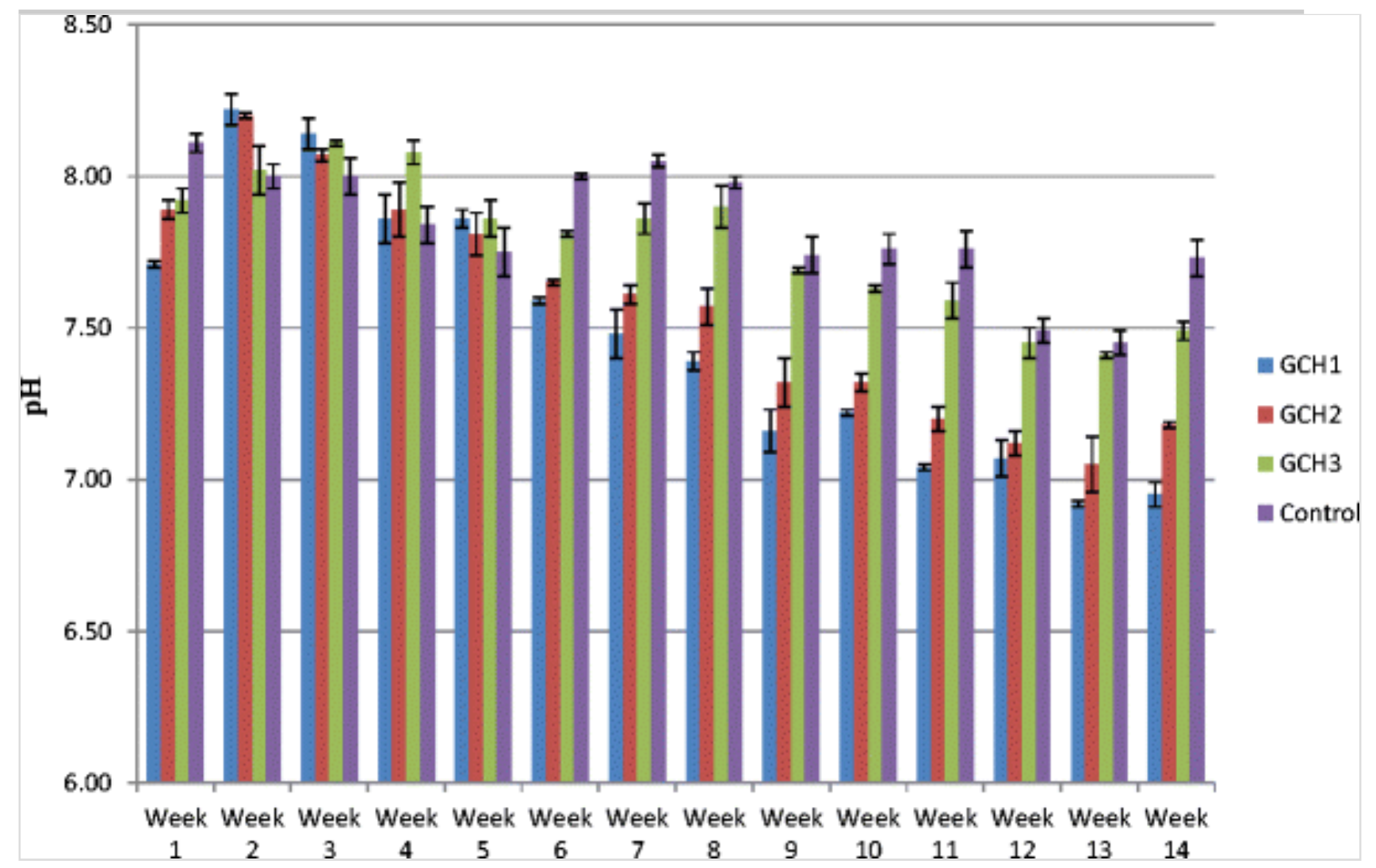

A generat The $\mathrm{pH}$ trend showed a decline in $\mathrm{pH}$ from the commencement of experiment until the end of the study for all treatments. However this was more pronounced in the GCH1 models as $\mathrm{pH}$ drifted and eventually fell below 7 while it remained above 7 in the other rigs. Since the sub-base was made up of limestone, it was understandable as to why initial background $\mathrm{pH}$ readings were above 7.7. Subsequent addition of contaminants altered the $\mathrm{pH}$ of the effluent in all test models as the $\mathrm{pH}$ declined throughout the duration of experiment. The $\mathrm{pH}$ reduction in the control model may have been influenced by the acidic sulphur compounds which are products of combustion in internal combustion engines via the added used oil. A significant difference $(p<0.05)$ existed between GCH1 and $\mathrm{GCH} 2$. According to the FAO (2008), the recommended $\mathrm{pH}$ range for irrigation water is 6.5-8.0. Furthermore, Bauder et al. (2008) and Harivandi (2008) noted that the standard range for $\mathrm{pH}$ of irrigation water 
is 6.5-8.4 while Peterson (1999) is of the opinion that a $\mathrm{pH}$ range of 6.08.5 is suitable for irrigation water. Since $\mathrm{pH}$ of all treatments were between 6.92 and 8.22 , these confirm that they are all within the recommended range of 6.0-8.5 and therefore, safe for irrigation purposes.

\section{Effluent turbidity}

The effluent turbidity showed that the turbidity of the effluent from GCH1 models was highest with peak value of 240 NTU while peak values for $\mathrm{GCH} 2, \mathrm{GCH} 3$ and control models were 110, 79 and 48 NTU, respectively (Fig. 7). There was significant difference $(p<0.05)$ between GCH1 and $\mathrm{GCH} 2$ models at any sampling point during contaminants addition phase of the study.

\section{Fig. 7}

Effluent turbidity. Error bars represent the mean \pm S.E. of three replicates. $\mathrm{GCH} 1=7200 \mathrm{mg} \mathrm{L}-1, \mathrm{GCH} 2=720 \mathrm{mg} \mathrm{L}-1$ and $\mathrm{GCH} 3=72 \mathrm{mg} \mathrm{L}-1$.

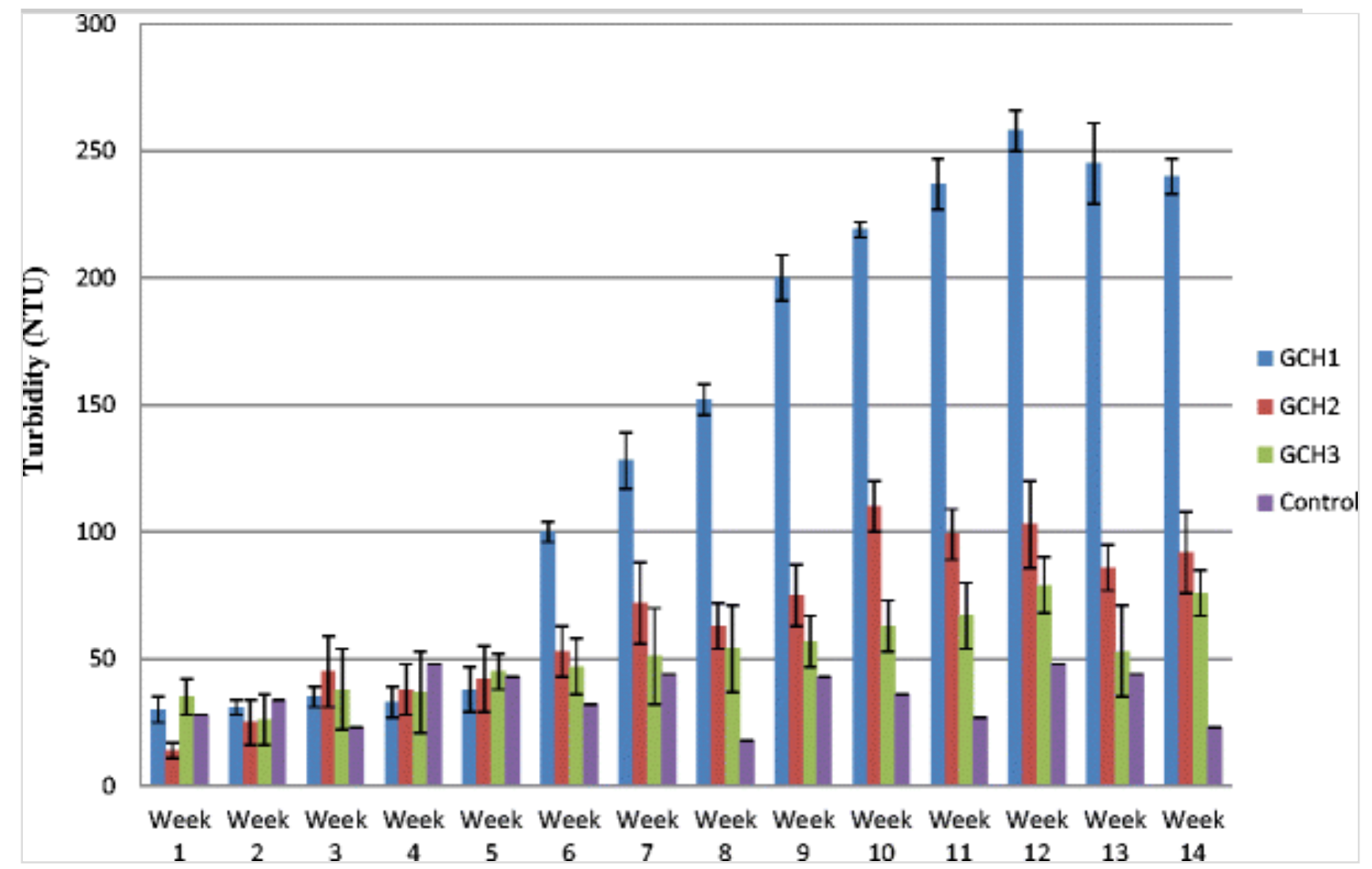

The turbidity of effluent from all the test models were relatively high throughout the duration of the experiment as the minimum values recorded before contaminants were added were 30, 14, 26 and 18 NTU in GCH1, $\mathrm{GCH} 2$, GCH3 and control models, respectively. It was even much higher in GCH1 models with values more than $50 \%$ higher than those recorded by 
for the next model, GCH2. This indicates the potency of $\mathrm{GCH}$ in washing contaminants and sediments through the rig system. For water intended for reuse purposes in urban environments; agricultural applications; environmental bodies (e.g. wetlands, aquatic habitats, stream flows, water bodies etc.); industrial applications; and groundwater recharge (aquifers that are not used as a potable source), both US EPA (2012b) and WHO (2006) recommend turbidity of $\leq 2$ NTU. From Fig. 7, turbidity of the effluents in all test models far exceeded the recommended limit for reuse standards. Turbidity has been found to promote the protection of microorganisms (Katz 1986; Schwartz and Levin 1999) and can cause an array of water purification challenges such as increased use of coagulants, decrease in filter run time, etc. (Murakami et al. 2013) as well as adverse effects on the ecosystem (Boyd 1990; Tazaki et al. 2003). Some studies observed that in environments where pathogens and turbidity occur in the same water source, the removal of pathogens occurs concurrently with the removal of turbidity (Ongerth and Pecoraro 1995; Schwartz and Levin 1999). As an important water pollution parameter, high concentration of turbidity can affect the BOD levels (Petts et al. 2002) and are frequently associated with suspended sediments via complex binding mechanisms (Rocher et al. 2004) and thus, may delay the residence time of contaminants (Foster and Charlesworth 1996). From the foregoing, it is clear that the impacts of turbidity increased as the concentration of $\mathrm{GCH}$ increased. Although the exact nature of these impacts may not be precisely known immediately, it should be further investigated and monitored to ensure optimum utilisation of the PPS structure is not compromised.

\section{Conclusions}

This study indicates that stormwater can be harvested from a PPS for reuse purposes. Stormwater is a resource that offers huge potential to augment water demand particularly for agricultural uses use such as irrigation of farms and gardens, amenity areas, golf courses, fountains, garden farms, toilet flushing and car washing. Sustainable drainage systems (SUDS) such as pervious pavement system (PPS) offers a potential for stormwater recycling and storage for these applications as stormwater can be recycled in the PPS to almost potable water quality in terms of hydrocarbon content and presence of heavy metals and thus, can be used where the use of potable quality water quality is unnecessary. Although the use of PPS is being promoted by Acts of Parliament in the UK and Best Management 
Practices (BMPs) in the USA, weed control on these structures using herbicides poses a challenge to the quality of water obtained from them. In this study, Results indicate results indicated that the highest Sodium Absorption Ratio(SAR) SAR of 1.6 recorded in this study, 1.6, is was less than that at which loss of permeability begins to occur and as well as deterioration of the matrix structure. Furthermore, the maximum Electrical conductivity (ECw) of $2990 \mu \mathrm{S} \mathrm{cm}^{-1}$, recorded for $7200 \mathrm{mg} \mathrm{L}^{-1}$ concentration was slightly below the unstable classification range at which salinity problem problems related to water quality eceurs occur such that the salts accumulate in the root zone to the extent that crop yields are adversely affected. However, GCH concentration of $720 \mathrm{mg} \mathrm{L}^{-1}$ was within exeellent 'permissible' range while that of $72 \mathrm{mg} \mathrm{L}^{-1}$ was within permissible 'excellent' range. Current study raises some environmental concerns owing to the overall impact that $\mathrm{GCH}$ at concentrations above $72 \mathrm{mg} \mathrm{L}^{-1}$ exerts on the net performance of the organic decomposers, heavy metal and hydrocarbon release from the system and thus, should be further investigated. However, effluent from all the test models including those dosed with high GCH concentration of $7200 \mathrm{mg} \mathrm{L}^{-1}$ do not pose any threat in terms infiltration or deterioration associated with salinity although, there are indications that high dosage of GCH could lead to an elevated electrical conductivity of the recycled water and thus, should be closely monitored.

\section{Acknowledgments}

This study was funded part-funded by Sustainable Drainage Applied Research Group at Coventry University while the PhD studentship was provided by Coventry University. Both are gratefully acknowledged.

\section{References}

Al-Shammiri M, Al-Saffer A, Bohamad S, Ahmed M (2005) Waste water quality and reuse in irrigation in Kuwait using microfiltration technology in treatment. Desalination 185:213-225

Amorós I, Alonso JL, Romaguera S, Carrasco JM (2007) Assessment of toxicity of a glyphosate-based formulation using bacterial systems in lake water. Chemosphere 67:2221-2228 
Andrea MM, Peres TB, Luchini LC, Bazarin S, Papini S, Matallo MB, Savoy VLT (2003) Influence of repeated applications of glyphosate on its persistence and soil bioactivity. Pesq Agrop Brasileira 38(11):13291335

Anzeec (2000) Australian and New Zealand water quality guidelines for fresh and marine waters. Australian and New Zealand Environment and Conservation Council, Canberra

Ashraf M, Harris P (2004) Potential biochemical indicators of salinity tolerance in plants. Plant Sci 166:3-16

Ayers RS, Westcot DW (1985) Water quality for agriculture, irrigation and drainage paper no. 29, revision I. F.A.O., Rome

Bailey D, Bilderback T, Bir D (1999) Water considerations for container production of plants (online). Available from

http://www.nurserycropscience.info/water/source-waterquality/extension-pubs/water-consideration-for-can-plantsncsu.pdf/view (Accessed 15/08/2014)

Bauder TA, Waskom RM, Davis JG (2008) Irrigation water quality criteria, Colorado State University: Extension-Agriculture 0.506 (online). Available from $<$ http://www.ext.colostate.edu/PUBS/crops/00506.html > (Accessed $15 / 04 / 2008)$

Bauder TA, Waskom RM, Sutherland PL, Davis JG (2011) Irrigation water quality criteria. Colorado State University, U.S. Department of Agriculture and Colorado counties cooperating, USA

Beck MW, Able DL, Childers DB, Eggleston B.M., Gillanders B., Halpern C.G., Hays (1989) The role of nearshore ecosystems. Issues in Ecology. Washington, D.C.: Ecological Society of America Beck, L. (1989) Habitat Buchenwald soil 1. Soil fauna and litter decompositionan overview. Ratio. Ges. Ecol., 17 (1989), 47-54

Bjerga A (2014) California drought transforms global food market. Bloomberg News 11August, 2014 (online) < 
http://www.bloomberg.com/news/2014-08-11/california-droughttransforms-global-food-market.html > (Accessed 27/08/2014)

Bond PC (1999) Mineral oil biodegradation within permeable pavements: long-term observations. Unpublished PhD Thesis, Coventry University, Coventry, UK

Borggaard OK (2011) Does phosphate affect soil sorption and degradation of glyphosate?-a review. Trends Soil Sci Plant Nutri 2:1

Boyd E (1990) Water quality in ponds for aquaculture. Auburn University, Auburn, p 482

Brownstein JB (1998) An investigation of the potential for the biodegradation of motor oil within a model permeable pavement. Unpublished PhD Thesis, Coventry University, Coventry, UK

Charlesworth SM, Mbanaso FU, Coupe SJ, Nnadi EO (2013) Utilisation of glyphosate-containing herbicides on pervious paving systems: laboratory-based experiments to determine impacts on effluent water quality. Clean - Soil, Air, Water 42(2):125-132

Coupe SJ (2004) Oil biodegradation and microbial ecology within permeable pavements. Unpublished $\mathrm{PhD}$ thesis, Coventry University, Coventry, UK

Coupe SJ, Smith HG (2006) The effect of glyphosate-containing herbicides on protozoan community structure. British Society for Protist Biology. Special Symposium on Molecular Ecology and Protozoa, Coventry Spring Conference. Available from http://www.protist.org.uk/abstracts/abstracts06.html (Accessed $15 / 06 / 12)$

Coupe SJ, Smith HG, Newman AP, Puehmeier T (2003) Biodegradation and microbial diversity within permeable pavements. Eur J Protistol 39:495-498

Coupe SJ, Nnadi EO, Charlesworth S (2010) Multiple benefits derived from the installation of permeable pavement systems. Proceedings: 
Novatech, GRAIE, Lyon, France

Curds RC (1982) The ecology and role of Protozoa in Aerobic sewage treatment processes'. Annu Rev Microbiol 36:27-46

Day GM, Hart BT, McKelvie ID, Beckett R (1997) Influence of natural organic matter on the sorption of biocides onto goethite, II. Glyphosate. Environ Technol 18:781-794

deHayr R, Gorden I (2006) Irrigation water quality, salinity and soil structure stability, factsheet QNRMO4191. Queensland Government, Department of Environment and Resource Management, Brisbane

Duncan RR, Carrow RN, Huck M (2000) Understanding water quality and guidelines to management. USGA Green Section Record. September - October, pp. $14-24$

European Environment Agency (2003) Drinking water quality [online]. Available from http://www.eea.europa.eu/data-andmaps/indicators/drinking-water-quality-1 (Accessed 27/11/2013)

FAO (2008) Wastewater quality guidelines for agricultural use (online). Available from http://www.fao.org/docrep/t0551e/t0551e04.htm [12/03/2014]

FAO (2013) Water scarcity (online). Available from http://www.fao.org/nr/water/topics_scarcity.html (Accessed 03/02/2014)

Fisher SW (1990) Changes in the toxicity of three pesticides as a function of environmental $\mathrm{pH}$ and temperature. Bull Environ Contam Toxicol 46:197-202

Foster IDL, Charlesworth SM (1996) Heavy metals in the hydrological cycle: trends and explanation. Hydrol Process 10:227-261

Gupta IC (1994) Re-assessment of standards for industrial effluents discharge on land for irrigation. Curr Agric 18(1-2):65-70

Halliwell DJ, Barlow KM, Nash DM (2001) A review of the effects of 
wastewater sodium on soil physical properties and their implications for irrigation systems. Aust J Soil Res 39(6):1259-1267

Harivandi MA (1982) The use of effluent water for turfgrass irrigation. Cooperative Extension: California Rurfgrass Culture 32(3 - 4)

Harivandi MA (2008) The use of municipal recycled water: agronomic, management and environmental issues. Agron Abstracts 723-724

Horneck DA, Ellsworth JW, Hopkins BG, Sullivan DM, Stevens RG (2007) Managing salt-affected soils for crop production. Pacific Northwest Extension publication, USA

Howe GE, Marking LL, Bills TD, Rach JJ, Mayer FL (1994) Effects of water temperature and $\mathrm{pH}$ on toxicity of terbufos, trichlorfon, 4nitrophenol and 2,4-dinitrophenol to the amphipod (Gammarus pseudolimnaeus) and rainbow trout (Oncorhynchus mykiss). Environ Toxicol Chem 13:51-66

Jambrak AR, Mason TJ, Lelas V, Herceg Z, Herceg LJI (2008) Effect of ultrasound treatment on solubility and foaming properties of whey protein suspensions. J Food Eng 86(2):281-287

Katz EL (1986) The stability of turbidity in raw water and its relationship to chlorine demand. Am Water Works Ass J 78:72-75

Kempenaar C (2010) Best practice for chemical weed control on hard surfaces. European glyphosate environmental information source, Wageningen University and Research Centre - Plant Research International

Kempenaar C, Lotz LAP, Riemens MM, Knol J (2006) Sustainable weed management on concrete block pavement. 8th International Conference on Concrete Block Paving, November 6-8, 2006 San Francisco, California USA

Kolpin DW, Thurman EM, Lee EA, Meyer MT, Furlong ET, Glassmeyer ST (2006) Urban contributions of glyphosate and its degradate AMPA to streams in the United States. Sci Total Environ 
Kristoffersen P, Rask AM, Grundy AC, Franzen I, Kempenaar C, Raisio J, Schroeder H, Spijker J, Verschwele A, Zarina L (2008) A review of pesticide policies and regulations for urban Amenity areas in seven European countries. Weed Res 48(3):201-214

Landschoot P (2014) Irrigation water quality guidelines for turfgrass sites (online). Available from http://plantscience.psu.edu/research/centers/turf/extension/factsheets/waterquality $(15 / 08 / 2014)$

Lee JJ, Leedale GF, Bradbury P (2000) An illustrated guide to the protozoa: organisms traditionally referred to as protozoa, or newly discovered groups, 2nd edn. Society of Protozoologists, USA

London Assembly (2005) Crazy Paving: the environmental importance of London's from gardens. London: Greater London Authority (online). Available from http://legacy.london.gov.uk/assembly/reports/environment/frontgardens.pdf (Accessed 24/11/2010)

Mamy L, Barriuso E (2005) Glyphosate adsorption in soils compared to herbicides replaced with the introduction of glyphosate resistant crops. Chemosphere 61:844-855

Mamy L, Gabriele B, Barriuso E (2008) Measurement and modelling of glyphosate fate compared with that of herbicides replaced as a result of the introduction of glyphosate-resistant oilseed rape. Pest Manag Sci 64(2008):262-275

Mbanaso FU, Coupe SJ, Charlesworth SM, Nnadi EO (2013) Laboratory-based experiments to investigate the impact of glyphosatecontaining herbicide on pollution attenuation and biodegradation in a model pervious paving system. Chemosphere 90:737-746

Mbanaso FU, Coupe SJ, Charlesworth SM, Nnadi EO, Ifelebuegu AO (2014) Potential microbial toxicity and non-target impact of different concentrations of glyphosate-containing herbicide in a model pervious 
paving system'. Chemosphere 100(2014):34-41

McConnell JS, Hossner LR (1985) pH-dependent adsorption isotherms of glyphosate. J Agric Food Chem 33:1075-1078

Mercer TG, Frostick LE (2012) Leaching characteristics of CCA-treated wood waste: a UK study. Sci Total Environ 427:165-174

Morillo E, Undabeytia T, Maqueda C (1997) Adsorption of glyphosate on the clay mineral montmorillonite: effect of $\mathrm{Cu}(\mathrm{II})$ in solution and adsorbed on the mineral. Environ Sci Technol 31:3588-3592

Morillo E, Undabeytia T, Maqueda C, Ramos A (2000) Glyphosate adsorption on soils of different characteristics. Influence of copper addition. Chemosphere 40:103-107

Murakami T, Suzuki Y, Oishi H, Ito K, Nakao T (2013) Tracing the source of difficult to settle fine particles which cause turbidity in the Hitotuse reservoir, Japan. J Environ Manag 120:37-47

Newman AP, Coupe SJ, Henderson J, Morgan JA, Puehmeier T, Pratt CJ (2001) Oil retention and microbial ecology in porous pavement structures. Coventry University, School of Science and The Environment, Coventry

Newman AP, Coupe SJ, Smith HG, Puehmeier T, Bond P (2006) The microbiology of permeable pavements. 8th International Conference on Concrete Block Paving. November 6-8, 2006 California USA

Newman AP, Nnadi EO, Duckers LJ, Cobley AJ (2011) Further developments in self-fertilising geotextiles for use in pervious pavements. Water Sci Technol 64(6):1333-1339

Nicolau A, Dias N, Mota M, Lima N (2001) Trends in the use of protozoa in the assessment of wastewater treatment. Res Microbiol 152:621-630

Nnadi EO (2009) An evaluation of modified pervious pavements for water harvesting for irrigation purposes. Unpublished $\mathrm{PhD}$ Thesis, 
Coventry University, UK

Nnadi EO, Newman AP, Puehmeier T (2008) An evaluation of the use of stored water derived from permeable paving systems for irrigation purposes. International Conference on Urban Drainage. 31st August -5th September, 2008 Held at Edinburgh Scotland CD-ROM

Nnadi EO, Duckers LJ, Newman AP, Coupe SJ, Puehmeier T (2009) Irrigation using permeable paving as the source of water: effects of recycled water on the soil; plant growth and development. Proceedings of the GeoAfrica 2009 Conference, Cape Town, South Africa

Nnadi E, Newman A, Duckers L, Coupe S, Charlesworth S (2012) Design and validation of a test rig to simulate high rainfall events for infiltration studies of permeable pavement systems. J Irrig Drain Eng 138(6):553-557

Nnadi EO, Newman AP, Coupe SJ (2013) Geotextile incorporated permeable pavement system as potential source of irrigation water: effects of re-used water on the soil, plant growth and development. Clean: Soil, Air, Water 42(2):125-132

Nnadi EO, Newman AP, Stephen J, Coupe SJ (2014) Geotextile incorporated permeable pavement system as potential source of irrigation water: effects of re-used water on the soil, plant growth and development. Clean: Soil, Air, Water 42(2):125-132

Nnadi EO, Newman AP, Coupe SJ, Mbanaso FU (2015) Stormwater harvesting for irrigation purposes: an investigation of chemical quality of water recycled in pervious pavement system. J Environ Manag 147:246-256

Ongerth JE, Pecoraro JP (1995) Removing Cryptosporidium using multimedia filters. Am Water Works Assoc J 87:83-89

Oster JD, Shainberg I (2001) Soil responses to sodicity and salinity: challenges and opportunities. Aust J Soil Res 39(6):1219-1224

Oster JD, Singer MJ, Fulton A, Richardson W, Prichard T (1992) Water 
penetration problems in California soils: prevention, diagnoses and solutions. In: Kearney Foundation of Soil Science, DANR, University of California, Riverside, CA

Papadimitriou C, Palaska G, Samaras P, Lazaridou M, Sakellaropoulos GP (2004) the relation of protozoan populations to activated sludge performance. protection and restoration of the environment VII, Mykonos

Patterson DJ (1992) Free-living freshwater protozoa: a colour guide. Wolfe Publishing Ltd, England

Patterson RA (1994) On-site treatment and disposal of septic tank effluent. Thesis for Doctor of Philosophy. University of New England. Armidale

Perry T, Nawz R (2008) An investigation into the extent and impacts of hard surfacing of domestic gardens in an area of Leeds, UK. Journal of Landscape and Urban Planning 86 (1) 1 - 13 (online). Available from http://www.sciencedirect.com (Accessed 26/11/2010)

Peterson HG (1999) Fact sheet: field irrigation and water quality. Agriculture and Agri-Food Canada-Prairie Farm Rehabilitation Administration: Agriculture and Agri-Food Canada. Available from http://www.safewater.org/PDFS/resourceswaterqualityinfo/Resource_Water_ $(17 / 09 / 2009)$

Petts GE, Heathcote J, Martin D (2002) Urban rivers: our inheritance and future, IWA Publishing/Environment Agency, 117 pp

Pratt CJ (1989) Permeable pavements for stormwater quality enhancement. Proceedings of an Engineering Foundation Conference: Urban stormwater quality enhancement-source control, retrofitting, and combined sewer technology. Switzerland: Davos platz

Pratt CJ, Newman AP, Bond PC (1999) Mineral oil bio-degradation within a permeable pavement long term observations. Water Sci Technol 39(2):103-109 
Pratt C, Wilson S, Cooper P (2002) Source control using constructed pervious surfaces: Hydraulic, structural and water quality issues (CIRIA C582). CIRIA Publications, London

Pritchard M, Mkandawire T, Edmondson A, O’Neill JG, Kululanga G (2009) Potential of using plant extracts for purification of shallow well water in Malawi. Phys Chem Earth 34:799-805

Ramwell CT, Heather AIJ, Shepherd AJ (2004) Herbicide loss following application to a railway. Pest Manag Sci 60:556-564

Rocher V, Garnaud S, Moilleron R, Chebbo G (2004) Hydrocarbon pollution fixed to combined sewer sediment: a case study from Paris. Chemosphere 54:795-804

Rodriguez-Hernandez J, Fernández-Barrera AH, Castro-Fresno D, VegaZamanillo A (2010) Long-term simulation of a system for catchment, pretreatment and treatment (SCPT) of polluted runoff water. J Environ Eng 136:1442-1446

Salvado H, Gracia MP, Amigo JM (1995) Capability of ciliated Protozoa as indicators of effluent quality in activated sludge plants. Water Res 29(4):1041-1050

Schwartz J, Levin R (1999) Drinking water turbidity and health. Epidemiology 10:86-90

Sonan LS, Saha U, Kissel DE (2012) Soil salinity testing, Data interpretation and recommendations. Cooperative Extesion, University of Georgia. U.S.A: CAES Publications

Spectrum Analytical Incorporated USA (2008) Guide to interpreting irrigation water analysis (online). Available from http://www.spectrumanalytic.com/support/library/pdf/guide_to_interpreting . (Accessed 15/08/2014)

Strosser P, Dworak T, Andrés P, Delvaux G, Berglund M, Schmidt G, Mysiak J, Kossida M, Iacovides I, Ashton V (2012) Gap analysis of the water scarcity and droughts policy in the EU. European Commission 
Tender ENV.D.1/SER/2010/0049 (online). Available from http://ec.europa.eu/environment/water/quantity/pdf/WSDGapAnalysis.pdf $>$ (Accessed 27/08/2014)

Suarez D, Wood D, Lesch S (2006) Effect of SAR on water infiltration under a sequential rain-irrigation management system. Agric Water Manag 86:150-164

Tazaki K, Sato M, Van Der Gaast S, Morikawa T (2003) Effects of clayrich river-dam sediments on downstream fish and plant life. Clay Miner $38: 243-253$

US EPA (2012) United States Environmental Protection Agency guidelines for water reuse 2012, EPA/600/R-12/618 | September 2012, Office of Wastewater Management, Office of Water, Washington, D.C.

Warrence KJ, Pearson KE, Bauder JW (2003) The basics of salinity and sodicity effects on soil physical properties. Bozeman USA: Land Resources and Environmental Sciences Department: Montana State University. Available from http://waterquality.montana.edu/docs/methane/basics.pdf (Accessed 19/09/2013)

WHO (2006) WHO guidelines for the safe use of wastewater excreta and greywater - volume 1 of policy and regulatory aspects. World Health Organisation Press, Switzerland

WHO (2014a) 10 facts about water scarcity (online). Available from http://who.int/features/factfiles/water/en/ (Accessed 03/02/2014)

WHO (2014b) The international decade for action: water for life 20052015 (online). Available from http://who.int/water_sanitation_health/decade2005_2015/en/index.html (Accessed 03/02/2014)

WHO (2015) The international decade for action: water for life 20052015 (online). Available from http://www.who.int/water_sanitation_health/decade2005_2015/en/ (Accessed 16/03/2015) 
Woodburn AT (2000) Glyphosate: production, pricing and use worldwide. Pest Manag Sci 56:309-312 